\title{
Pembuatan dan Uji Organoleptik Hand Sanitizer dari Daun Mangga (Mangifera indica) dengan Metode Maserasi
}

\author{
Dwi Ardiana Setyawardhani ${ }^{1 \mathrm{a} *}$, Cindy Mei Saputri ${ }^{2 \mathrm{~b}}$, Nafi'Atun Ni'mah $^{2 \mathrm{c}}$ \\ ${ }^{1}$ Program Studi Sarjana Teknik Kimia, Fakultas Teknik, Universitas Sebelas Maret \\ 2 Program Diploma III Teknik Kimia, Sekolah Vokasi, Universitas Sebelas Maret \\ Jl. Ir. Sutami 36A Jebres, Surakarta, Jawa Tengah 57126 Indonesia \\ E-mail:a Dwiardiana@staff.uns.ac.id (corresponding author), b cindymei333@gmail.com, \\ cnafifhia@gmail.com
}

\begin{abstract}
Mango leaf extracts contain alkaloids, polyphenols, saponins, tannins, flavonoids that function as antimicrobial compounds to inhibit bacterial growth. This study aims to make a hand sanitizer from mango leaves extract, analyze the organoleptic properties of the product, and identify the phytochemical content. Dried mango leaves were macerated using solvents at room temperature for $3 \times 24$ hours with a change of solvent every day, then filtered until the filtrate was obtained. The filtrate is then evaporated with a vacuum evaporator at $65^{\circ} \mathrm{C}$ until the volume is reduced $80 \%$ from the initial volume. The resulting extract is then processed into a hand sanitizer in gel form. Mango leaf extracts are then subjected to phytochemical tests. The results indicated that phytochemical content in mango leaves were flavonoids, alkaloids, polyphenols, tannins, and also saponins that have the potential as a natural antibacterial in making hand sanitizers. Organoleptic analysis results of hand sanitizer gel preparations showed yellowish-green color, mango leaves odor, soft, non-sticky and moist gel texture, cold use properties and quickly absorbed when applied to the hands.
\end{abstract}

Keywords: Hand sanitizer, maceration, mango leaf extracts

EQUILIBRIUM Volume 4 No.1 July 2020

Online at http:/ / equilibrium.ft.uns.ac.id 



\section{Pendahuluan}

Mangga adalah salah satu jenis buah tropis yang banyak dikonsumsi masyarakat Indonesia sebagai buah musiman. Pohon mangga cenderung ditanam untuk diambil buahnya, sementara daunnya cenderung dibiarkan berguguran menjadi sampah. Daun mangga yang berguguran, oleh sebagian besar masyarakat hanya dibakar dan akhirnya menyebabkan polusi udara. Untuk itu ide pengolahan daun mangga untuk dapat menghasilkan manfaat lain semisal sebagai bahan anti bakteri, menjadi menarik.

Pemanfaatan bahan alam yang berasal dari tumbuhan sebagai obat tradisional telah lama dilakukan oleh masyarakat Indonesia. Hal ini dapat menangani berbagai masalah kesehatan yang telah dipercaya secara turuntemurun, salah satunya adalah penyakit infeksi [1]. Penyakit infeksi merupakan penyebab paling utama tingginya angka kesakitan (mordibity) dan angka kematian (mortality) terutama pada negara-negara berkembang seperti halnya Indonesia. Salah satu penyebab penyakit infeksi adalah bakteri patogen, contohnya Staphylococcus aureus dan Eschericbia coli [2]. Staphylococcus aureus merupakan bakteri gram positif yang hidup sebagai saprofit di dalam saluran membran tubuh manusia, permukaan kulit, kelenjar keringat, dan saluran usus [3]. Bakteri Escherichia coli adalah bakteri gram negatif yang normal di usus manusia dan dapat menyebabkan Infeksi Saluran Kemih (ISK) dan diare [4].

Tanaman yang mengandung minyak atsiri, tanin dan flavonoid dapat menghambat aktivitas mikroba dengan mendenaturasi protein dan merusak dinding sel bakteri, serta merusak lipid pada membran sel melalui mekanisme penurunan tegangan permukaan membran sel [5]. Ekstrak daun mangga dilaporkan memiliki kandungan alkaloid, fenol, saponin, kumarin, tanin, flavonoid, triterponoid, steroid, dan glikosida yang berfungsi sebagai senyawa antimikrobia yang dapat menghambat pertumbuhan bakteri [6] dan jamur [7]. Kandungan flavonoid berfungsi sebagai antibakteri dengan beberapa mekanisme aksi, di antaranya menghambat sintesis asam nukleat, menghambat fungsi membran sitoplasma dan menghambat metabolisme energi dari bakteri.

Hand sanitizer merupakan salah satu jenis kosmetik yang sering digunakan sebagai pembersih tangan. Produk hand sanitizer memungkinkan masyarakat membersihkan tangan secara lebih cepat dan mudah tanpa memerlukan air dan sabun, sehingga praktis untuk dibawa. Kelebihan hand sanitizer dapat membunuh kuman dalam waktu relatif cepat, karena mengandung senyawa alkohol seperti etanol, propanol atau isopropanol. Pada masa pandemi virus Covid-19 seperti sekarang ini, penggunaan hand sanitizer menjadi kebutuhan pokok yang tidak boleh ditinggalkan, khususnya untuk kondisi di tempat yang tidak bisa mencuci tangan dengan sabun, misalnya saat bepergian.

\section{Metodologi}

Bahan utama yang diperlukan dalam penelitian ini adalah daun mangga dan pelarut yang meliputi metanol teknis, etanol 70\% dan etanol 96\% untuk memperoleh ekstrak daun mangga. Sedangkan untuk pembuatan hand sanitizer, diperlukan bahan-bahan tambahan meliputi tri etilamin (TEA), propilen glikol, karbomer, gliserin, nipagin, pewangi dan aquadest. Rangkaian peralatan ditunjukkan pada Gambar 1, yang meliputi rangkaian ekstraktor dan mixing.

Penelitian dan pembuatan produk dilakukan di laboratorium Proses Teknik Kimia, Universitas Sebelas Maret. Tahap awal dalam penelitian ini adalah penyiapan bahan baku yaitu daun mangga berjenis arumanis. Daun mangga yang diperoleh kemudian diolah menjadi simplisia kering dengan pengovenan pada suhu $50^{\circ} \mathrm{C}$ selama 3 hari dan dihaluskan menggunakan blender. Serbuk simplisia kering sebanyak 40 gram dimaserasi dalam $400 \mathrm{ml}$ metanol pada suhu ruangan selama $3 \times 24$ jam dengan pergantian pelarut setiap harinya kemudian disaring hingga diperoleh filtrat. Filtrat kemudian diuapkan dengan vacuum evaporator pada suhu $65^{\circ} \mathrm{C}$ sampai volumenya berkurang $80 \%$ dari volume awal. Ekstrak kental yang dihasilkan dilakukan uji fitokimia di antaranya uji alkaloid, flavonoid, polifenol, saponin, dan tanin. 


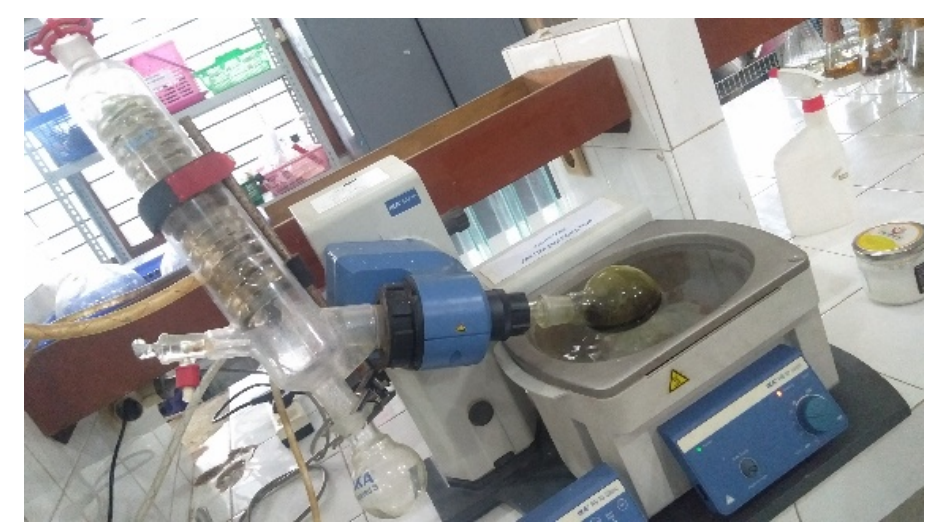

Gambar 1. Proses Pembuatan Ekstrak

Tahap berikutnya yaitu pembuatan gel hand sanitizer. Ekstrak yang dihasilkan diolah menjadi hand sanitizer dalam bentuk gel dengan cara melarutkan karbomer dalam akuades lalu dipanaskan pada suhu $80-90^{\circ} \mathrm{C}$ hingga larut sempurna. Setelah karbomer larut, suhu diturunkan menjadi $30^{\circ} \mathrm{C}$ dan dilakukan penambahan Triethanolamine (TEA) sambil diaduk hingga terbentuk gel. Selanjutnya dilakukan penambahan gliserin, propilen glikol, nipagin, ekstrak daun mangga dan pewangi aroma mangga dengan pengadukan hingga semua bahan tercampur. Gel hand sanitizer yang dihasilkan diuji homogenitas dan uji organoleptik.

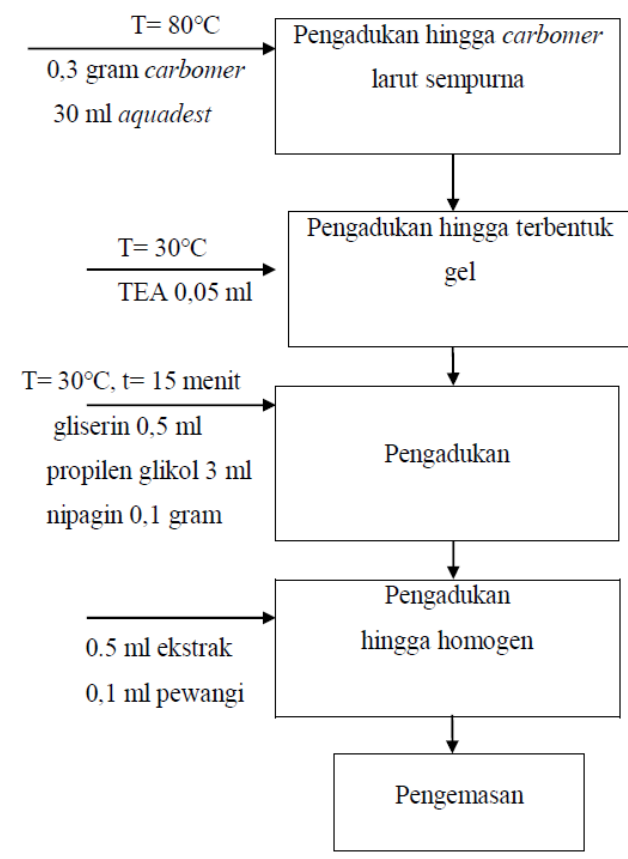

Gambar 2. Blok diagram pembuatan hand sanitizerer dari ekstrak daun mangga

\section{Hasil dan Pembahasan}

\section{a. Hasil Pembuatan Ekstrak Daun Mangga}

Pembuatan ekstrak daun mangga menggunakan metode maserasi dengan pelarut methanol, 40 gram daun mangga dapat menghasilkan 35,74 gram berat ekstrak (rendemen sebesar 10,02\%). Maserasi adalah proses ekstraksi simplisia dengan menggunakan pelarut dengan beberapa kali pengocokan atau pengadukan dalam temperatur ruangan (kamar). Maserasi bertujuan untuk menarik zat-zat berkhasiat yang tahan pemanasan maupun yang tidak tahan pemanasan. Metode maserasi dipilih karena metode ini murah dan mudah dilakukan dengan alat yang sederhana. Jenis pelarut yang digunakan memberikan hasil yang berbeda karena kelarutan 
suatu senyawa tergantung (salah satunya) adalah pada polaritas komponen solute dan solvent. Polaritas pelarut berkurang sesuai urutan air $>$ metanol $>$ etanol. Senyawa yang terlarut cenderung merupakan senyawa yang kurang polar, sehingga perolehan ekstrak juga menurun seiring dengan peningkatan polaritas pelarutnya. Di samping itu, adanya perbedaan senyawa metabolit sekunder yang dapat dilarutkan oleh jenis pelarut tertentu, sehingga berpengaruh terhadap daya hambat dari ekstrak.

Tabel 1. Filtrat Hasil Proses Maserasi

\begin{tabular}{lc}
\hline Pelarut & Volume Filtrat $(\mathbf{m l})$ \\
\hline Metanol & 250 \\
Etanol $70 \%$ & 236 \\
Etanol $96 \%$ & 255 \\
\hline
\end{tabular}

\section{b. Uji Fitokimia Ekstrak Metanol Daun Mangga}

Uji fitokimia merupakan uji kualitatif yang digunakan untuk mengetahui adanya golongan senyawa metabolit sekunder seperti alkaloid, flavonoid, polifenol, tanin dan saponin dalam daun mangga. Zat aktif yang terkandung dalam ekstrak daun mangga dapat diketahui melalui metode uji fitokimia menggunakan tabung reaksi [8]. Pada uji ini, ekstrak yang digunakan adalah ekstrak daun mangga hasil maserasi dengan pelarut metanol. Hasil fitokimia ekstrak daun mangga dapat dilihat pada Tabel 2.

Tabel 2. Hasil Identifikasi Senyawa Kimia Ekstrak Metanol Daun Mangga

\begin{tabular}{llc}
\hline \multicolumn{1}{c}{ Senyawa } & \multicolumn{1}{c}{ Warna } & Hasil \\
\hline Flavonoid & Merah/Jingga & Ada \\
Alkaloid & Endapan putih & Ada \\
Polifenol & Hijau kehitaman & Ada \\
Tanin & Hijau kehitaman & Ada \\
Saponin & Busa yang stabil & Ada \\
\hline
\end{tabular}

c. Uji Karakteristik Homogenitas

Uji homogenitas merupakan uji untuk mengetahui apakah seluruh komponen dalam sediaan telah terdistribusi secara merata. Bentuk sediaan gel yang baik menurut SNI adalah sediaan gel yang tidak terdapat bulir-bulir atau butiran kasar pada sediaan. Bulir-bulir dapat terbentuk ketika proses pengembangan karbomer tidak sempurna. Sediaan gel memiliki tekstur yang lembut dan dapat menyerap ketika dioleskan di tangan. Hasil uji karakteristik homogenitas tercantum pada Tabel 3.

Tabel 3. Uji Karakteristik Homogenitas

\begin{tabular}{ll}
\hline \multicolumn{1}{c}{ Karakteristik } & \multicolumn{1}{c}{ Hasil } \\
\hline Tekstur & Lembut \\
Bulir & Tidak terdapat bulir kasar \\
Kecepatan menyerap & Cepat \\
Warna & Bercampur merata \\
\hline
\end{tabular}

\section{d. Analisa Organoleptik Produk}

Dalam pengamatan organoleptis, pengujian dilakukan untuk mengetahui karakteristik produk yang disesuaikan dengan selera publik terhadap hand sanitizer yang beredar di pasaran. Pengujian dilakukan dengan 
menggunakan variabel aroma, warna, dan karakteristik produk setelah digunakan pada tangan. Dari pengamatan yang dilakukan oleh 20 responden, didapatkan hasil pengujian seperti pada Tabel 4-6.

Tabel 4. Analisa Organoleptik Produk

\begin{tabular}{lll}
\hline Variabel & Hand sanitizer Daun Mangga & Hand Sanitizer Komersial \\
\hline Warna & Hijau kekuningan & Bening \\
Aroma & Khas & Harum \\
Sifat penggunaan & Dingin, tidak lengket & Dingin, tidak lengket \\
\hline
\end{tabular}

Tabel 5. Tingkat Kesukaan Responden

\begin{tabular}{lcccc}
\hline \multicolumn{1}{c}{ Sifat Organoleptik } & Sangat Suka & Suka & Kurang Suka & Tidak Suka \\
\hline Warna & 8 orang & 10 orang & 2 orang & - \\
Aroma & 10 orang & 10 orang & - & - \\
Sifat Penggunaan & 6 orang & 14 orang & - & - \\
Tingkat Penyerapan & 5 orang & 12 orang & 3 orang & - \\
Tekstur Gel & 10 orang & 9 orang & 1 orang & - \\
\hline
\end{tabular}

Tabel 6. Persentase Sifat Organoleptik yang Dipilih oleh Responden

\begin{tabular}{llcc}
\hline Sifat Organoleptik & \multicolumn{1}{c}{ Pilihan } & Responden yang memilih & Persentase \\
\hline \multirow{3}{*}{ Warna } & Hijau Kekuning-kuningan & 14 orang & $70 \%$ \\
& Kuning & 6 orang & $30 \%$ \\
& Hijau & - & - \\
& Warna lain & - & - \\
\hline \multirow{3}{*}{ Aroma } & Daun mangga & 12 orang & $60 \%$ \\
& Metanol & - & - \\
& Tengik & - & - \\
& Aroma lain & 8 orang & $40 \%$ \\
\hline Tekstur Gel & Gel merata, lembut & 19 orang & $95 \%$ \\
& Gel tidak merata, lembut & - & - \\
& Gel tidak merata, tidak lembut & - & - \\
& Tekstur gel lain & 1 orang & $5 \%$ \\
\hline \multirow{3}{*}{ Sifat Penggunaan } & Dingin, lengket, kering & 2 orang & $10 \%$ \\
& Dingin, tidak lengket, tidak kering & 11 orang & $55 \%$ \\
& Tidak dingin, tidak lengket,tidak kering & 2 orang & $10 \%$ \\
& Sifat penggunaan lain & 5 orang & $25 \%$ \\
\hline \multirow{3}{*}{ Tingkat Penyerapan } & Cepat menyerap & 15 orang & $75 \%$ \\
& Tidak cepat menyerap & 3 orang & $15 \%$ \\
& Kurang menyerap & 1 orang & $5 \%$ \\
& Tingkat penyerapan lain & 1 orang & $5 \%$ \\
\hline
\end{tabular}

Dari pengujian organoleptis, produk hand sanitizer daun mangga secara keseluruhan cukup diminati oleh responden. Sebanyak 18 responden (8 responden sangat suka dan 10 responden suka) dari total 20 responden menyukai warna dan 2 responden di antaranya kurang menyukai warna dari hand sanitizer daun mangga. Sebanyak 20 responden (10 responden sangat suka, 10 responden suka) menyukai aroma, 20 responden (6 responden sangat suka, 14 responden suka) menyukai sifat penggunaan, sebanyak 17 responden (5 responden sangat suka dan 12 responden suka) dari total 20 responden menyukai tingkat penyerapan dan 3 responden

Pembuatan dan Uji Organoleptik Hand Sanitizer dari Daun Mangga (Mangifera indica) 
di antaranya kurang menyukai tingkat penyerapan dari hand sanitizer daun mangga. Sebanyak 19 responden (10 responden sangat suka dan 9 responden suka) dari total 20 responden menyukai tekstur gel dan 1 responden di antaranya kurang menyukai tekstur dari hand sanitizer daun mangga,

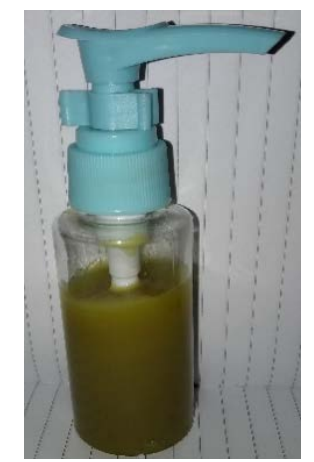

Gambar 3. Produk Hand Sanitizer Daun Mangga

Gambar 3 menunjukkan produk jadi hand sanitizer dari ekstrak daun mangga. Produk ini memiliki karakteristik yang hampir sama dengan formulasi hand sanitizer komersial. Banyaknya ekstrak daun mangga mempengaruhi warna sediaan hand sanitizer. Hal ini disebabkan ekstrak daun mangga berwarna hijau, sedangkan beberapa produk hand sanitizer komersial seperti merk Dettol, Antis, dan Nuvo bewarna bening. Produk hand sanitizer perlu dibuat berwarna bening agar lebih menarik konsumen. Aroma yang dihasilkan beraroma khas daun manga dan kurang harum sehingga perlu ditambahkan pewangi untuk meningkatkan daya tarik produk. Pada pembuatan hand sanitizer ditambahkan metil paraben atau nipagin yang berperan sebagai pengawet untuk mencegah kerusakan pada sediaan gel. TEA berperan dalam menetralkan karbomer serta meningkatkan viskositas sediaan. Propilen glikol merupakan zat yang berfungsi menstabilkan gel. Sedangkan gliserin dalam formulasi sediaan gel hand sanitizer berperan sebagai pelembab yang berguna untuk menghindari rasa kering pada kulit saat pemakaian.

\section{Kesimpulan}

1. Metode yang paling efektif untuk mengekstrak daun mangga adalah metode maserasi karena peralatan yang digunakan relatif sederhana, proses pengerjaan mudah dilakukan dan dapat digunakan untuk mengekstraksi senyawa yang bersifat termolabil karena metode maserasi ini dilakukan tanpa pemanasan.

2. Kandungan fitokimia yang berada di dalam daun mangga adalah flavonoid, alkaloid, polifenol, tanin, dan juga saponin yang berpotensi sebagai antibakteri alami dalam pembuatan hand sanitizer.

3. Secara umum dari uji organoleptis, produk hand sanitizer daun mangga cukup diminati oleh responden berdasarkan warna, aroma, sifat penggunaan, tingkat penyerapan, dan tekstur gel.

\section{Referensi}

[1] M. C. Nuria, A. Faizatun, and Sumantri, "Uji Aktivitas Antibakteri Ekstrak Etanol Daun Jarak Pagar (Jatropha curcas L) Terhadap Bakteri Staphylococcus aureus ATCC 25923, Escherichia coli ATCC 25922, dan Salmonella typhi ATCC 1408," Mediagro, vol. 5, no. 2, pp. 26-37, 2009.

[2] Darmadi, Infeksi Nasokomial: Problematika dan Pengendaliannya. Jakarta: Penerbit Salemba Medika, 2008.

[3] M. J. Peleczar and E. C. S. Chan, Dasar-Dasar Mikrobiologi. Jakarta: UI Press, 1988.

[4] E. Jawetz, J. L. Melnick, and E. A. Adelberg, Mikrobiologi Kedokteran, XXII. Jakarta: Penerbit Salemba Medika, 2001.

[5] S. Shetty and K. K. Vijayalaxmi, "Phytochemical Investigation of Extract/Solven Fractions of Piper ningrum Linn, Seeds and Piper betle Linn, Leaves," Int. J. Pharma Bio Sci., vol. 3, no. 3, pp. 344-349, 
2012.

[6] A. C. Nugraha, A. T. Prasetya, and S. Mursiti, "Isolasi, Identifikasi, Uji Aktivitas Senyawa Flavonoid sebagai Antibakteri dari Daun Mangga," Indones. J. Chem. Sci., vol. 6, no. 2, 2017.

[7] D. R. Ningsih, Zushafair, and D. Mantari, "Ekstrak Daun Mangga ( Mangifera indica L .) sebagai Antijamur terhadap Jamur Candida albicans dan Identifikasi Golongan Senyawanya," J. Kim. Ris., vol. 2, no. 1, pp. 61-68, 2017.

[8] J. B. Harborne, Metode Fitokimia: Penuntun Cara Modern Menganalisis Tumbuban. Bandung: Institue Teknologi Bandung, 1987. 